\title{
Desenho rococó nos manuscritos do Brasil do século XVIII: caminhos e expressões
}

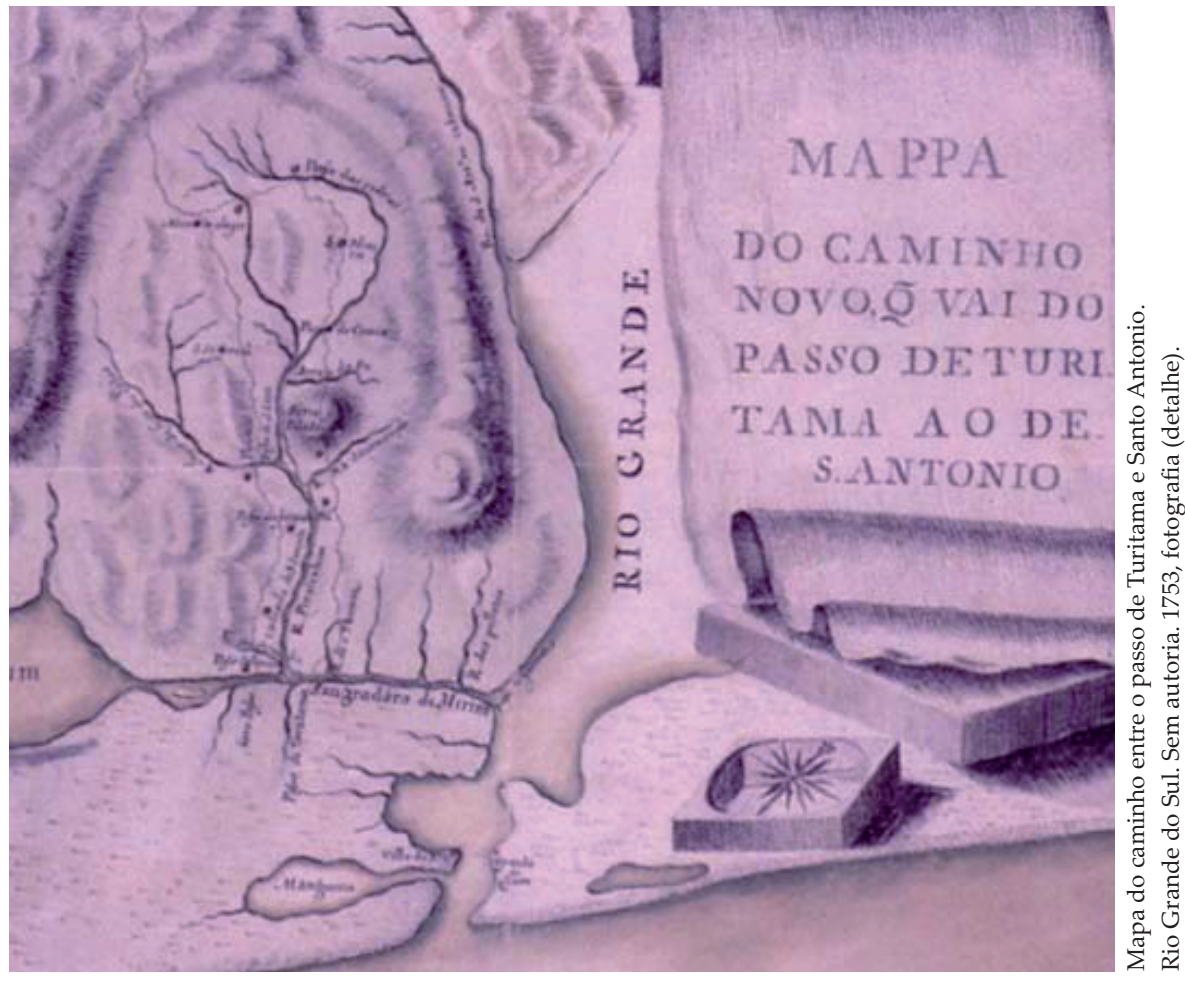

\section{Antonio Wilson Silva de Souza}

Doutor em História da Arte pela Universidade do Porto, de Portugal. Professor de História da Arte e de Desenho Artístico em vários cursos de graduação e de Teoria e História da Arte no Programa de Pós-graduação em Desenho, Cultura e Interatividade da Universidade Estadual de Feira de Santana (UEFS). antoniowilsonsilv@gmail.com 


\section{Desenho rococó nos manuscritos do Brasil do século XVIII: caminhos e expressões}

Rococo drawing in eighteenth-century brazilian manuscripts: routes and expressions

\section{Antonio Wilson Silva de Souza}

\begin{abstract}
RESUMO
Este artigo aborda origens, características e difusão do rococó, destacando, de modo especial, a ornamentação dos manuscritos do Brasil no século XVIII. Apesar dos estudos realizados sobre o estilo, as peculiaridades do desenvolvimento do rococó merecem uma análise sempre atualizada e pormenorizada, sobretudo para se entender melhor a influência que a gravura francesa exerceu sobre a criação, o desenvolvimento e a propagação do estilo na Europa e no Brasil. A ênfase na ornamentação gráfica fundamenta o exame das suas particularidades, ao possibilitar maior entendimento sobre o significado que o desenho assume como manifestação autêntica da arte, o que permite afirmar que o rococó se tornou uma singular realidade na expressão da arte brasileira. PALAVRAS-CHAVE: ornato; rococó; arte brasileira.
\end{abstract}

\begin{abstract}
The present article considers the origins, characteristics and diffusion of the rococo, highlighting, especially, ornamentation in eighteenth-century Brazilian manuscripts. Despite the existence of stylistic studies, the peculiarities of rococo development deserve analysis that is always current and detailed, above all in order to understand better the influence that Frenchen graving exercised over the creation, development and diffusion of the style in Europe and Brazil. An emphasis on graphic ornamentation is the basis of the analysis concerning the particularities of the style, making possible a greater understanding of the significance which the design assumes as an authentic manifestation of art and allowing it to be established that the rococo became a singular reality in Brazilian artistic expression.
\end{abstract}

KEYWORDS: ornate; rococo; Brazilian art.

O conhecimento sobre o estilo rococó é devedor de um considerável número de obras de arte, estudos e pesquisas, hoje integrantes do acervo de bibliotecas, arquivos e museus com reconhecido mérito internacional. De crédito inconteste, essas instituições reservam largo espaço à produção dimanada do mundo acadêmico-científico, cujos autores (pesquisadores na sua maioria) revelam um sublinhado desejo de descortinar ainda mais as particularidades do também alcunhado estilo rocaille.

Nascido imediatamente após o estilo barroco, de cujo húmus extraiu, em boa parte, os nutrientes de seu pronunciado gosto decorativo, o rococó se viu entendido como extensão daquele estilo, permanecendo, deste modo, e por muito tempo, a ele vinculado como subordinado e dependente. E essa visão foi mantida e propalada por um número expressivo de historiadores da arte.

O clarão das luzes do rococó se fez perceber pela primeira vez em 
Paris, no século XVIII. ${ }^{1}$ Nasceu com o predominante objetivo de revestir os espaços habitados e frequentados pela burguesia e nobreza francesas e, aos poucos, se tornou um engenho artístico de fino trato ornamental. Contudo, na nascente, recebeu, de grande parte dos seus contemporâneos, um olhar depreciativo, visto que estavam habituados com o barroco que, apesar das inovações estilísticas propostas, acolhia as linhas gerais do clássico. Foi chamado, segundo essa visão detratora, de "gosto pitoresco" ou "gosto moderno". ${ }^{2}$ No entanto, o que designavam por esses termos nada mais eram que composições exibidoras de figuras bizarras. Tais figuras, cuja inclusão e predominância soavam descabidas, eram conhecidas na arte europeia, como bem podem provar os grotescos do renascentista Rafael Sanzio e as torsas figurações em água-forte de Jacques Callot, seiscentista francês. A observável recorrência de figuras estranhas - à época já conhecidas -, acompanhada de metódica assimetria e do abuso de formas curvas, dá configuração ao interesse pelo exótico, proporcionando, desta sorte, o surgimento do então chamado "gosto moderno". Os artistas do estilo rococó abandonaram o peso decorativo do barroco, para apresentar obras comum fulgor ornamental mais delicado, no entanto, assumiram a liberdade de expressões fantasistas. Mesmo em meio à visão desqualificativa de que foi objeto, o rococó se disseminou pela Europa, alcançando destacada posição no universo das artes decorativas.

Com identidade definida, de clara verve ornamental, o rococó assinalou várias expressões da arte setecentista europeia, de modo particular a arquitetura (fachadas e interiores), o mobiliário, a tapeçaria e a joalheria. Difundiu-se também na América, chegando ao Brasil, onde deu mostras de existência desde o século XVIII, vindo, no entanto, a se consolidar, enquanto estilo, em meados do século XIX.

Na arte brasileira, o rococó trilhou uma senda equiparável à dos seus ascendentes europeus. Por essa razão, há frequentes e significativas pesquisas sobre o estilo, de modo especial, na área da arquitetura e do mobiliário. No entanto, não é habitual encontrar referências ao rocaille no Brasil, no domínio da ornamentação gráfica, mais especificamente, na decoração de manuscritos. Assim, a realização de um recente estudo sistemático ${ }^{3}$ direcionado a esse tema tornou possível indagar e buscar substratos para atualizar a análise da produção rocaille. Esse espaço aberto instiga a novo olhar sobre abrangência e peculiaridades do rococó.

\section{O ornato: paradigma do estilo rocaille}

Um estudo que tematize o estilo rococó requer uma prévia reflexão sobre a concepção do seu elemento paradigmático: o ornato. Assunto controverso, o conceito de ornato nunca assistiu a uma convergência de entendimento na história da arte. Ponto de discordância, foi, por vezes, compreendido fora do seu contexto e, em decorrência, uma leitura desenraizada o reduziu a acessório. Nessa direção, sublevaram-se teorias de cunho tradicionalista que "como verdadeiras fórmulas antiornamentais conferiram ao ornamento um caráter complementar, como se, em sua retirada, não viesse a sofrer nenhum tipo de prejuízo senão estético e formal" ${ }^{4}$

A ênfase no ornato como mero aparato a auxiliar na busca de datação e procedência de obras de arte tornou-o um simples recurso estilístico, o que reforçou sua dependência como expressão artística. Em contraposição a essa visão, o ornato é aqui assumido como tradutor da capacidade humana
${ }^{1}$ Para datação inicial do estilo rococó, seguimos referências da maior conhecedora da história da ornamentação rococó no mundo luso-brasileiro: MANDROUX-FRANÇA, Marie-Thérèse. Information artistique et 'mass media' au XVIII ${ }^{\text {ème }}$ siècle: la diffusion de l'ornement grave rococó au Portugal. Bracara Augusta, v. 27, n. 64, Braga, 1973.

${ }^{2}$ Essas denominações, que assumimos neste artigo, são referências da pesquisadora MANDROUX-FRANÇA, Marie-Thérèse, op. cit. p. 4.

${ }^{3}$ Trata-se da investigação científica empreendida no estágio pós-doutoral (out. 2015-set. 2016), na Universidade Paris I - Panthéon Sorbonne, com a colaboração do Professor Doutor Jacinto Lageira. O projeto de pesquisa intitulado "O rococó e a linguagem do desenho no século XVIII: influências da arte francesa na ornamentação de manuscritos luso-brasileiros", obteve apoio financeiro da Capes. Neste texto se lança mão de pesquisas realizadas durante o pós-doutoramento.

${ }^{4}$ PEDRONI, Fabiana. Por uma definição do ornamento. Atas do IX Encontro de História da Arte: circulação e trânsito de imagens e ideias na História da Arte. Campinas, Unicamp/ IFCH/CHAA, 2013, p. 80. 
${ }^{5}$ BONNE, Jean-Claude. De l'ornement à l'ornementalité: la mosaïque absidiale de San Clement de Rome. Actes $d u$ Colloque International: le rôle de l'ornement dans la peinture murale du Moyen Âge. Poitiers, Université de Poitiers, 1997, p. 103: "sa première fonction est de celébration, quelle que soit par ailleurs la capacité des motifs ornementaux à remplir d'autres fonctions (symboliques, magiques, rituelles...)" (tradução nossa).

${ }^{6}$ Ver REY, Alain. Dictionnaire de la langue française. Paris: Le Robert, 2000. Considerando a fonte linguística das línguas portuguesa e a francesa, a base etimológica do vocábulo "ornato" é a mesma. Assim, igual concepção de ornato permeia o repertório lusófono e o francófono. À vista disso, o recurso a esse léxico da língua francesa reforça nosso entendimento. Ademais, é bom ter presente que o 'ornato rococó', objeto deste artigo, teve origem circunscrita à cultura francesa, tornando, assim, pertinente esse apoio lexical de fundamento francofônico. de criar e abstrair, de gerar e transformar, de individualizar e universalizar. Concebida desse modo, a ornamentação ganha foro de expressão artística em si mesma. Reconhecido ao ornamento seu grau de autêntica obra de arte, "sua função primeira é de celebração, qualquer que seja, aliás, a capacidade dos motivos ornamentais de cumprir a outras funções (simbólicas, mágicas, rituais ...)". ${ }^{5}$

Um outro aporte vem também reafirmar a concepção de ornato como obra de arte em si. Trata-se da etimologia da palavra 'ornato' que se origina na língua latina 'ordo' ${ }^{6}$, com significado de 'ordem' e fundamenta o conceito de beleza na Antiguidade Clássica. Com base na genealogia linguística, a palavra ornato traduz o belo por ser gerado com o propósito de transcrever a beleza presente na natureza. Ademais, os latinos, em cujas origens terminológicas aqui buscamos fundamento, beberam de ainda mais longínqua fonte, que dava testemunho do harmonioso entrecruzar das concepções de ordem e de beleza. A tríade fundamental da filosofia grega assim o entendia. Sócrates, Platão e Aristóteles reconheciam que se alcança a beleza através da imitação da Natureza. E nesse aspecto, importa dimensionar o peso da palavra "imitar" na cultura da Grécia antiga que, em relação à criação de uma obra de arte, significava muito mais que transpor elementos para uma nova composição. A imitação traduzia o respeito pela proporção, pelo equilíbrio, pela harmonia, dentre outros fatores observáveis da natureza. A eleição e agregação de componentes da natureza direcionava a elaboração de uma nova ordem. Nesse sentido, no que se refere ao estilo rococó, o ornato caracteriza essa habilidade de ordenar, ou reordenar, elementos da cultura visual antecedente ou coeva do século XVIII; dessa atuação 'organizadora' têm origem composições de singular identidade a contribuir para a implantação e estabelecimento do perfil estilístico.

Tomada apenas sob o prisma da transmutação e composição, ou recomposição, de símbolos, a estética rocaille não se apresentaria como inusitada, nem apontaria singularidade. Pondo, contudo, a ênfase nos caprichosos elementos figurativos, na frugalidade requintada do surto ornamental e na luminosidade atenuada e oposta ao marcado contraste do barroco, pode-se chancelar ao rococó o posto de linguagem de elevada qualidade estética na arte de ornamentar, o que, aliás, constituía a sua especificidade.

O valor estético do rococó delata o papel que o ornato exerceu na geração e no estabelecimento da arte do século XVIII. Este valor, aliás, alcançou nas estampas seu meio mais habitual de disseminação e nos manuscritos, encontrou um recorrente espaço de expressão.

\section{O desenho (ornato) rococó: percursos e propagação}

As fronteiras cronológicas e boa parte das balizas temporais indicativas na história da arte são porosas, permitindo um certo grau de fluidez no estabelecimento da periodização dos estilos. Por essa razão, não se pode apenas considerar os referenciais matematicamente estabelecidos (século, década, ano etc.) como único fator delimitador para o enquadramento temporal dos estilos. A pluralidade de fatores implicados no processo de datação, tais como a política, a cultura, a geografia, dentre outros, leva a não negligenciar também a base filosófica que, associada aos demais aspectos, interfere na maturação estética. Sem esse entendimento, dificilmente se 
alcançaria uma visão realista da sociedade, da gênese e desenvolvimento da arte, como de resto tornaria dubitável a caracterização dos múltiplos e cambiantes estilos artísticos.

Pondo ênfase somente na ornamentação em geral, a dificuldade para firmar periodização é mais intensa, por força de seu pertencimento (segundo visão tradicional), como adereço (ou acréscimo), à variadas expressões da arte. No entanto, apesar dessa dificuldade, a tradicional análise histórica mantém o ano de 1700, na França, como delimitação para o começo da fase de criação do rococó7, ou o que se poderia chamar 'proto-rococó'. O estilo rococó atingiu seu apogeu na França, entre 1730 e 1765. Contudo, é bom deixar claro que as circunstâncias ideais para o seu nascimento ocorreram durante o reinado de Luís XV (1715-1774), e por essa razão é também conhecido pelo nome deste rei. ${ }^{8}$ Essas datas já acolhidas pela história da arte são igualmente válidas para a história específica da ornamentação, considerando que o ornamento configura a face mais característica do estilo rocaille.

No que se refere à ornamentação de manuscritos, objeto em destaque no presente texto, o estabelecimento de cronologia para o estilo é muito frágil, porque não sendo o desenho considerado, à época (século XVIII), uma arte autônoma, não alcançou reconhecimento de sua dimensão estética. Embora os manuscritos sejam datados, os ornatos que neles tomaram forma interpenetram os limites de estilos variados, em que se reflete o movimento gradual das correntes artísticas. Correspondendo às demandas das demais expressões da arte, às quais se integrava como elemento estruturante subjacente, o desenho, mesmo apresentando essa noção de projeto ${ }^{9}$, não se viu elevado, no século XVIII, ao patamar de expressão artística autônoma. Esse pormenor, aliado ao caminhar descompassado entre as diversas técnicas artísticas, criou para a história do rococó uma periodização que não encontra equivalência plena com a ornamentação de manuscritos.

Para se entender melhor a história da ornamentação rococó, convém considerar as fases por que passa um estilo até chegar a sua plenitude: criação e maturação, implantação e estabilidade. Estas últimas etapas são garantidas, em boa parte, pela publicidade dos princípios fundantes do estilo, pela vulgarização de seu caráter (sua compleição), o que decorre dos meios disponíveis de difusão que permitem a evolução, a expansão e o desdobramento do paradigma do estilo.

A difusão de um estilo se dá, geralmente, através da propagação do padrão visual que o caracteriza e que é mantido pela pluralidade de expressões artísticas que o acolhem. Os primeiros exemplares do rococó chegaram à luz no final do terceiro decênio do século XVIII, na França. E, devido ao aperfeiçoamento dos métodos de imprensa na época, a difusão mais usual desse estilo ocorreu através das estampas, que serviam como meio de comunicação, codificando a informação visual oferecida na fase de produção. Atente-se para o fato que a produção se fundava na transcrição gráfica de uma obra de arte pré-existente para a configurar em outra técnica. Contribuem também para a difusão do estilo as consequentes tiragens, as redes comerciais, as cópias e falsificações, bem como a utilização que era feita das imagens. ${ }^{10}$ Essa recepção ou utilização do padrão estilístico é de importância para o estudo sobre a ornamentação de manuscritos, como se verá um pouco mais adiante.

O emprego da estampa nos séculos XVII e XVIII fundamenta um entendimento mais lúcido sobre a ornamentação em geral e permite co-

${ }^{7}$ Ver MANDROUX-FRANÇA, Marie-Thérèse, op. cit.

${ }^{8}$ Ver HUNTER-STIEBEL, Penelope. The continuing curve. In: COFFIN, Sarah D. et al. Rococo: the continuing curve, 1730-2008. New York: Smithsonian's Cooper-Hewitt, National Design Museum, 2008.

${ }^{9}$ Uma substancial referência para o aprofundamento dessa questão é GOMES, Luiz Vidal Negreiros. Desenhismo. 2. ed. Santa Maria: Editora daUFSM, 1996. A leitura deste livro permite-nos afirmar que, em meio a constatações bibliográficas e documentais, se encontram registros de exaltação do desenho enquanto técnica de representação, sobretudo como auxiliar na execução de outras expressões da arte. Era recomendada a aprendizagem do desenho, em vários manuais de desenho dos séculos XVII, XVIII e XIX, sobretudo aqueles devotados à formação militar. Verdadeiro paradoxo: o desenho não gozava do estatuto de arte autônoma e, ainda assim, outras fontes também recomendavam seu domínio, apresentando-se mesmo como material de caráter pedagógico auxiliar no aprendizado do desenho, como era o caso dos manuais de caligrafia.

${ }^{10}$ Ver HERMAN, Sandrine. Estampes de l'ornementsous Louis $X I V$ : création, interpretation \& réception de l'oeuvre gravée de Paul Androuet du Cerceau (vers 1630-1710). Thèse (Doctorat) - École Doctorale VI-Paris IV/La Sorbonne, Paris, 2008, p. 1. 
${ }^{11}$ Ver idem.

${ }^{12}$ No original: "Le véritable créateur du rococó ornemental". MANDROUX-FRANÇA, Marie-Thérèse, op. cit, p. 8 (tradução nossa).

${ }^{13}$ Ver idem, op. cit.

${ }^{14}$ THUILLIER, Jacques. Catalogues de la collection d'estampes de D. Jean V, roi de Portugal. Organisée par Marie-Thérèse Mandroux-França. Lisbonne/ Paris: Fundação Calouste Gulbenkian/Bibliothèque Nationale de France-Fundação da Casa de Bragança, 2003, p. 27.

${ }^{15}$ KLAUSING, Flávia Gervásio. O rococó religioso no Brasil e seus antecedentes europeus. Varia História, v. 20, n. 31, Belo Horizonte, jan. 2004, p. 279 e 280 . nhecer melhor a feição rocaille da decoração de manuscritos. Porém, há aqui certa dose de dificuldade, porque não se trata somente da tentativa por uma circunscrição cronológica da produção ornamental, mas sobretudo de, paralelamente, penetrar um horizonte visual de composições e confrontações que propiciam embasado diagnóstico do caráter dinâmico de uma obra gravada. ${ }^{11}$

Desta sorte, a difusão da estampa levou também à difusão do rococó, que se espalhou pela Europa e também pela América, onde ocupou expressivo lugar no universo das artes visuais. Uma série de estampas foi responsável por esse feito, sendo que algumas das quais foram extraídas de uma coleção de estampas intitulada Livre d'ornementsinventés et dessinés, publicada em 1733, cujo autor, o francês Juste-Aurèle Meissonnier (16951750), considerado por Mandroux-França como "o verdadeiro criador do rococó ornamental"12, deu indiscutível contribuição para a disseminação do ornamento tipicamente rocaille. ${ }^{13}$ Sob o impulso dessa coletânea de estampa de ornamento, como das coevas de mesma e diversa autoria, todas regidas por forte tom ornamental, o estilo rococó também se viu aplicado às laudas de manuscritos que se imbuíram da estilística vigente. Nesse contexto em que a estampa se tornou "fonte de uma outra História da Arte"14, o rococó colheu frutos do desenvolvimento editorial que tinha, então, como centros irradiadores a França e a Alemanha, sendo que esta última, nesse processo, se destacava.

É também importante ressaltar o processo de internacionalização do estilo, através do intercâmbio de obras e artistas, mas, principalmente, por meio da divulgação em fontes impressas. Com a ascensão do mercado editorial de livros leigos - que tinha nas cidades francesas e na cidade germânica de Augsburg, seus principais centros irradiadores -, se deu a circularidade dos elementos constitutivos do rococó através dos tratados teóricos, manuais e gravuras, usados permanentemente nas oficinas e levados para terras distantes da Europa Central, Portugal e colônias, onde foram, posteriormente, reinventados. ${ }^{15}$

Os autores citados, portanto, constataram que, em paralelo à gravura, houve outros meios de divulgação do rococó, fazendo menção a tratados de arquitetura e a manuais, entre os quais, podemos incluir, sem restar dúvida, aqueles dedicados à aprendizagem da caligrafia. Todavia, a gravura se sobressaia dos demais meios pelo seu forte impacto visual e pela sua aceitação social, razão por que desempenhou significativo papel na disseminação do paradigma do estilo. Com base nisso, se pode resumir essencialmente o percurso do ornato rocaille: estampa (gravura) - pintura decorativa - escultura, em geral, e estuque. Ponto de partida desse caminho, a estampa era fonte segura para pintores. A imagem impressa serviu de modelo a escultores e estucadores que, em trabalho colaborativo nos ateliers, não somente a copiavam, reproduzindo-a na inteireza, mas também a recriavam, reinventando, assim, os signos do estilo.

O desenvolvimento e a difusão do estilo rococó possibilitam entender melhor a própria natureza da arte de ornamentar, como também permitem aprofundar o conhecimento sobre a ornamentação dos manuscritos do Brasil no século XVIII. No entanto, tendo em mente os desdobramentos de que se imbuiu a arte de ornamentar, este estudo assume um caráter de desbravamento de um território com trilhas ainda a seguir. Esse investimento, entretanto, torna-se significativo e necessário porque pode 
conduzir a reconhecer o desenho como uma autêntica manifestação da arte setecentista brasileira.

\section{O rococó no desenho: os manuscritos e sua ornamentação}

A convergência da atenção nos manuscritos encontra plausível justificativa para sua incorporação à presente reflexão sobre o rococó no desenho. De fato, os vínculos entre esse estilo artístico e o ornamento presente na literatura manuscrita se pautam sobre conexões históricas que confessam, e de certo modo emblematizam, a relação entre a escrita e o desenho. Uma outra razão vem também respaldar o olhar para essa associação: apesar do progresso das técnicas de impressão na Europa, a cultura no Brasil do século XVIII se manteve basicamente manuscrita. ${ }^{16} \mathrm{E}$ os manuais de caligrafia ${ }^{17}$ que circulavam no mundo luso-brasileiro o comprovam.

Perpetrava a cultura brasileira setecentista a necessidade de aprender a escrever, o que impulsionou o desenvolvimento da habilidade de representação gráfico-visual, visto que o domínio da caligrafia evocava um saber sobre ornamentação e, por essa razão, conduzia à prática do desenho. Em estudo precedente ${ }^{18}$, foi possível constatar a dileção da sociedade do Brasil do século XVIII pela aprendizagem da escrita que, em evidente paralelismo, estimulava a destreza na técnica do desenho à pena para poder estampar as laudas dos documentos manuscritos (civis, militares e eclesiásticos) com primorosos ornamentos. A respeito do mérito de que se reveste o ato de escrever e, por consequência, a produção que dele resulta, é cabível mencionar que o manuscrito "possuía um caráter simbólico que não pode ser menos-prezado: singularidade, beleza e ineditismo eram paradigmas cultivados ainda durante o século XVIII. Nestes casos, a ornamentação dos documentos e a caligrafia erudita aumentavam o valor simbólico do objeto". ${ }^{19}$

Desse modo, se foram tornando constantes, na consciência do mundo subtropical de domínio lusitano de então, as possibilidades de expressão gráfico-ornamental que se poderia galgar por meio do exercício do desenho. Elaborado recurso da comunicação escrita, o desenho, através do seu tom decorativo, acolhia os padrões estéticos dos estilos da arte, motivo pelo qual o manuscrito se tornou, no século das Luzes, locus indispensável para a realização de esmeradas composições de caris barroco. Convém aqui explicitar que, sob a invocação da palavra barroco, seja entendida não somente a unidade artística, mas também um sistema cultural e civilizacional. No entanto, é necessário afirmar que, se coube ao barroco a preponderância enquanto estilo que ultrapassou o âmbito da arte - impregnando toda a cultura, a mentalidade, da Europa seiscentista e do Brasil setecentista -, cumpriu também à estética rococó certo grau de coetâneo comparecimento, cuja dosagem foi suficiente para fertilizar a ação de decorar manuscritos, deixando, por seu turno, na cultura e na arte, um bem pronunciado vinco de fulgor ornamental.

Caprichosos como os traços barrocos, os ornatos rococós apresentam, no entanto, uma desconcertante sobriedade, firmando identidade às composições que, na sua quase totalidade, reservavam largo espaço à fantasia. Toda a investida ornamental do período baseava-se em um desenho no qual as regras compositivas, derivadas do estudo dos clássicos, cediam lugar à liberdade do autor, do artista. ${ }^{20}$ Em relação ao rococó, essa liberdade tem origem no seu desprendimento das amarras ideológicas. A mais renomada

${ }^{16}$ Verificar informações mais aprofundadas a esse respeito em ALMADA, Márcia. Livoros manuscritos iluminados na era moderna: compromissos de irmandades mineiras. Dissertação (Mestrado em História) - FFCHF-UFMG, Belo Horizonte, 2006.

${ }^{17} \mathrm{Um}$ dos mais destacados, sobretudo pela ornamentação que emprega e divulga, é de autoria do brasileiro Manuel Andrade de Figueiredo, publicado em Lisboa em 1722: A nova escola para aprender a ler, escrever e contar. O uso desse manual dá testemunho do apreço ao aprendizado da escrita no século XVIII, seja em Portugal, quanto no Brasil.

${ }^{18}$ Ver SOUZA, Antonio Wilson Silva de Souza. O desenho no Brasil do século XVIII: ornato de documentos e figurinos militares. Tese (Doutorado em Letras) - Universidade do Porto, Porto, 2008.

${ }^{19}$ ALMADA, Márcia. Caligrafia artística no século XVIII: Brasil e Portugal enlaçados nas letras de Manoel de Andrade de Figueiredo. Navegações: Revista de Cultura e Literaturas de Língua Portuguesa, v. 4, n. 2, Porto Alegre, jul.-dez. 2011, p. 172.

${ }^{20}$ Ver COLLE, Enrico. Il mobille rococó in Italia: arredi e decorazioni dal 1738 al 1775. Milano: Electa, 2003. 
${ }^{21}$ OLIVEIRA, Myriam Andrade Ribeiro de. Barroco e rococó nas igrejas do Rio de Janeiro. Brasília: IPHAN/Programa Monumenta, 2008, v. 1, p. 139.

${ }^{22}$ Importa ressaltar que a sociedade francesa do século XVIII viu surgir, em seu seio, o Iluminismo, que atribuía valor ao desenvolvimento da razão, portanto, de forte teor humanista, como também todo o processo que, na década de 80 , eclodirá na Revolução Francesa, trazendo consigo os direitos humanos e os ideais libertários. Sem dúvida, esses e outros impulsos de natureza ideológica e política influenciaram os artistas e, por conseguinte, o estilo rococó que, apesar de não ter demonstrado sujeição a nenhuma instituição específica, acolheu a desdobramentos naturais da evolução da sociedade da época.

${ }^{23}$ Sobre o assunto, ver ADÃO, Áurea. Estado absoluto e ensino das primeiras letras: as escolas régias (1772-1794). Lisboa: Fundação Calouste Gulbenkian, 1997.

${ }^{24}$ Em Portugal e no Brasil do século XVIII, aqueles que aprendiam a escrever o faziam com o auxílio de um mestre de primeiras letras que, via de regra, se beneficiavam de manuais de caligrafia. Estes ensinavam a escrever, ler e contar. Porém, apresentavam estampas de ornamento que deveriam ser copiadas e, desse modo, tinham também claro objetivo de ensinar a desenhar, ou seja, ornamentar. Em geral, os aprendizes da escrita eram apenas homens membros da família real e os comerciantes.

${ }^{25}$ No original, "piaceri dela sorpresa". COLLE, Enrico, op. cit. p. 7 (tradução nossa).

${ }^{26} \mathrm{Idem}$.

${ }^{27}$ Tomamos esse empréstimo do étimo francófono para dar maior ênfase à excentricidade original do estilo rococó.

${ }^{28}$ Ver DAVIDSON, Gail S. Ornamento of bizarre imagination. Rococo prints and drawings from cooper-hewitt's Léon Decloux Collection. In: COFFIN, Sarah D. et al., op. cit.

${ }^{29}$ No original: "sinuous, organic, sensuous - that is the mantra of this project". HUNTER-STIEBEL, Penelope, op. cit., p. 1 (tradução nossa). autoridade no rococó no Brasil, Myriam Ribeiro, admite a dificuldade no entendimento do estilo que deixou sinais na arquitetura e na mobiliária brasileiras, nos períodos colonial e imperial, ao afirmar que o rococó "é de mais difícil compreensão que o barroco, em virtude do descompromisso de origem desse estilo com qualquer tipo de ideologia, de natureza religiosa ou até mesmo política". ${ }^{21}$ Os rompantes do desenho barroco nasciam de acentuado impulso da esfera emocional, a retratar temas, na maioria das vezes, de cunho religioso; os desenhos rococós se originavam do engenhoso terreno da fantasia e, desatados dos grilhões da religião, davam vida às composições quiméricas que somente uma mão consciente da liberdade de expressão, dos desprendimentos ideológicos ${ }^{22}$ poderia realizar.

No que tange à ornamentação gráfica, essa liberdade dava mostra de maior flexibilidade, cuja abrangência alcançava um raio de proporções jamais visto. É bom ter presente que aqueles que sabiam escrever gozavam de credibilidade e respeito no mundo luso-brasileiro. ${ }^{23}$ Assim, é muito pouco provável que o domínio da ornamentação de manuscrito tivesse sido alvo de vigilância e censura. ${ }^{24}$ Nesse contexto, a iconografia rococó se viu acrescida de elementos fantasiosos advindos da consciência e do exercício de uma assentada liberdade expressiva.

Esse caráter de criação desvinculada de amarras ideológicas fez avultar na ornamentação rocaille a tendência a exibir o inusitado. A propensão ao inabitual deriva-se do fato que o rococó, ao contrário do barroco, buscava preponderantemente tematizar a vida secular e galante da sociedade; não uma expressão contida nos meandros de regras religiosas, mas a vivência de uma liberdade que evocava os "prazeres da surpresa" 25 , vertente que compõe a base desse estilo. No rococó, é exatamente a busca do inusitado para surpreender o espectador que move o artista, razão pela qual as composições do estilo são esquematicamente labirínticas, refletindo uma configuração típica dos jardins franceses. Deste modo, a fruição é direcionada para a busca do excepcional em cada pormenor, que se torna, por essa via, uma janela entreaberta a descortinar um horizonte de múltiplas interpretações e sensações. A busca da surpresa, radicada em uma expressão desatada, é a motriz das ornamentações próprias da estética rocaille.

Todavia, o florescimento do rococó não se explica somente pela liberdade de expressão. A oratória barroca foi rejeitada em função de critérios que punham a ênfase no "pitoresco", no caprichoso, no "maravilhoso". Em paralelo, registrava-se uma vertiginosa procura por variada tipologia ornamental, sem, contudo, se negligenciar o apreço pela ordem compositiva necessária à elaboração e ao bom êxito de uma obra de $\operatorname{arte}^{26}$, postura que deixa injustificadas as ferrenhas críticas de que o rococó foi objeto na sua origem.

Por princípio, a ornamentação típica do estilo rocaille apresenta contornos extraordinários, uma confusa mistura de indiscriminados atributos, elementos "bizarros" 27 aguçados pela imaginação do artista. Seguindo essa direção, os desenhos decorativos de manuscritos exibiam uma irregular e confusa composição de juncos, palma, e uma variedade de plantas imaginárias que tanto provocaram tumulto no mundo da decoração. ${ }^{28} \mathrm{Bem}$ analisado, o "sinuoso, orgânico e sensual - que é o mantra desse projeto [rococó]" 29 consagrou os 'prazeres da surpresa' sem, contudo, pôr em causa as premissas da linguagem visual; tornou solene o fantasioso sem, porém, descurar a atenção ao realismo clássico; celebrizou o exótico mas - por paradoxo! - rendeu culto ao trivial. É por estampar o selo dessas proprie- 
dades que, em grande parte, refletem aspirações de cunho social, que o ornato rocaille detém distinto e indiscutível valor estético. Considerando essa reflexão, pode-se afirmar que, assim como o barroco ${ }^{30}$, o rococó foi não apenas um estilo da arte, mas um estilo de vida.

Irrompida na Europa do Setecentos, a mentalidade rocaille é atestada pelo conjunto de impressos daquela centúria. Parte significativa desses documentos foi compulsada por nós ao longo de um ano de pesquisa de pós-doutorado (out. 2015-set. 2016), na França, efetivada em algumas das mais célebres e fidedignas instituições, tais como a Biblioteca Nacional de Paris (de modo especial, no Setor de Estampas e Imagens), no Instituto Nacional de História da Arte e na Biblioteca do Museu de Artes Decorativas. A documentação compulsada se compõe, na sua quase totalidade, de estampas, a modo de pranchas individuais ou reunidas em volumes, cujos autores (decoradores e gravadores) tiveram atuação na França a partir de 1730. Alguns lograram reconhecimento à época, em razão de suas estampas serem consideradas como modelo para a arte da ornamentação de então. Dentre eles se deve, por mencionar, aqui, Juste-Aurèle Meissonnier (16951750). ${ }^{31}$ Toda a produção desse ornamentador ${ }^{32}$, e de outros que lhe deram prosseguimento, se tornou mais conhecida através da ação dos editores, em especial da Alemanha, que, acolhedores da expressão ornamental de origem francesa, a copiaram e a divulgaram. A publicação de estampas foi a garantia de difusão nacional e internacional do estilo rococó. Expandiu-se, assim, pela França e por outros países da Europa, entretanto, teve como centro difusor a Alemanha do Sul.

Augsburg era, no começo do século XVIII, um centro editorial muito ativo e um importante difusor da circulação internacional dos modelos de ornamentos gravados. Editores como Jeremias Wolff (?-1724) fez lá uma especializada imitação de estampas estrangeiras, que eles exportavam em seguida para a Europa ou para a América Latina. Em Portugal, em particular, os ornamentos franceses [...] foram conhecidos, não somente em suas edições originais, mas sobretudo por suas imitações [...] alemãs das quais os mais numerosos exemplares estão ainda conservados nas coleções nacionais. ${ }^{33}$

As edições francesa e alemã foram, assim, as primeiras responsáveis pela difusão do rococó na Europa, através das estampas de ornamento, que eram elaboradas à guisa de modelo. Para se ter uma ideia do papel das edições de estampas na difusão do rococó, cabe aqui referir que em Portugal, na primeira metade do século XVIII, “o novo estilo foi apenas conhecido através de gravuras". ${ }^{34}$

Devido à temática abordada neste texto, torna-se importante fazer menção ao fato que "circulavam no mundo português, do Ocidente e do Oriente, e pela Europa, os riscos, ou coleções de estampas, de manuais e tratados, que serviam de modelos aos artistas". ${ }^{35}$ De fato, "a circulação de modelos e estampas [portanto] foi uma prática muito comum [também] na América portuguesa". ${ }^{36} \mathrm{E}$ a mentalidade estética da época o exigia. Sem contar que o entroncamento de símbolos animado pelo uso da estampa orientou uma proposta estilística motivadora da criatividade dos artistas, a maioria dos quais nem sempre adstrita às artes decorativas, o que indica possibilidade de uma transposição de divisas dos gêneros artísticos.

Em Portugal, as estampas mantiveram função especial no desenvolvimento das artes decorativas, sobretudo a partir do reinado (1707-1750)
${ }^{30}$ Muitos historiadores da arte consideram o barroco um estilo de vida, mais do que um simples estilo artístico. É o caso de Maria Helena Occhi Flexor.

${ }^{31}$ Ver MANDROUX-FRANÇA, Marie-Thérèse, op. cit. Segundo a pesquisadora, outros houve que tiveram atuação, tais como Jacques de Lajoue (1687-17610, p. e. Babel (1720-1775), F. de Cuvilliers (1698-1786) e F. Boucher (1703-1770). Destes, no entanto, encontramos pouca referência que fosse de real interesse para o presente estudo, razão pela qual, preferimos apresentar Meissonnier, considerado o genitor do rococó ornamental.

32 Ver LIEURE, Jules. La gravureen France au XVeme siècle: la gravure dans le livre et l'ornement. Paris et Bruxelles: Librairie Nationale d'Art d'Histoire G. Van Oest, Éditeur, 1927, p. 4. No original: "Vers la fin du XIXème siècleon a appelé les artistes qui avaient utilisé cet artles 'ornemaniste"”. "No fim do século XIX se começou a chamar os artistas que se dedicavam a essa arte de 'os ornamentadores'” (tradução nossa).

${ }^{33}$ Idem, ibidem, p. 6. No original: "Augsburg était au début $\mathrm{du}$ XVIII ${ }^{\text {ème }}$ siècle un centre d'edition três actif et un relais important de la circulation internacional e des modèles d'ornements gravés. Des éditeurs comme Jeremias Wolff (?-1724) s'y étaient fait une spécialité de la contrefaçon d'estampes étrangères, qu'ils exportaient ensuite en Europe ou en Amérique Latine. Au Portugal, em particulier, desornemanistes français [...] furent connus, non seulement em leurs éditions originales, ma surtout par des contrefaçons [...] allemandes don't de plus nombreux exemplaires sont encore consevés dans les collections nationales" (tradução nossa).

${ }^{34}$ OLIVEIRA, Myriam Andrade Ribeiro de, op. cit., p. 497.

${ }^{35}$ FLEXOR, Maria Helena Occhi. Escultura barroca brasileira: questões de autoria. Disponível em <https://www.upo.es/depa/ webdhuma/areas/arte $/ 3 \mathrm{cb} /$ documentos/39f.pdf $>$. Acesso em 10 fev. 2018.

${ }^{36}$ NÓBREGA, Michael Douglas dos Santos. Circulação de imagens lusitanas no Além-Mar: 
cultura histórica e cultura artística na azulejaria barroca de Teotónio dos Santos na Paraíba colonial. Dissertação (Mestrado em História) - UFPB, João Pessoa, 2015, p. 44.

${ }^{37}$ PEREIRA, José Fernandes e PEREIRA, Paulo (orgs.). Dicionário da arte barroca em Portugal. Lisboa: Presença,1989, p. 248.

${ }^{38}$ Ver MANDROUX-FRANÇA, Marie-Thérèse, op. cit.

${ }^{39}$ KLAUSING, Flávia Gervásio, op. cit., p. 280 e 281 . do "magnânimo", D. João V, monarca que teve como um dos nortes de seu governo investir no florescimento das artes e, para tanto, encomendou "vários volumes de gravura dos mais notáveis gravadores da época, destinados à Biblioteca do Paço Real". ${ }^{37}$ Dom João V chegou até mesmo a contratar artistas, equipe de gravadores, com a finalidade de ilustrar as edições da Academia Real de História. ${ }^{38}$ Esse procedimento, em verdade, nunca foi estranho aos reis europeus do tempo do Iluminismo. E os registros dessa investida se fazem notar também além-mar, pois devido à colonização portuguesa, no Brasil há testemunhos verídicos da influência na arte do século XVIII que absorveu a estética rococó, apesar da vigência do barroco. Das Minas Gerais de então, encontram-se exemplos portadores de peculiaridades dignas de máxima atenção e, por esse motivo, mais adiante, encontrarão aqui destaque.

A circularidade propiciada pelas fontes impressas permitiu à colônia brasileira receber a influência não só de Portugal, mas também da região da Alemanha e da França e, juntamente com as tradições locais, realizou-se um mosaico de interpretações do estilo rococó. É elucidativo pensar a aproximação entre o rococó germânico e aquele produzido em Minas - muitas vezes o que se delega como "original", é uma peculiaridade do rococó religioso - e também a grande semelhança entre as duas sociedades, visto que, em ambas, a maioria dos artistas eram locais, formados em oficinas e eram fortemente ligados às tradições artísticas próprias da região e ao seu tipo específico de sensibilidade estética. ${ }^{39}$

Uma leitura e análise da ornamentação gráfica apresentada nos manuscritos deixa em evidência o seu vínculo com as estampas, lúcida consequência do processo de produção e circulação dessas gravuras. Processo que proporcionou a expansão do estilo rococó, que se proliferou de maneira a deixar sulcos na arte de ornamentar em todas as sociedades que tenha alcançado. É oportuno, e de certo modo torna-se uma questão de justa distinção, conduzir à esta reflexão um testemunho da propagação do estilo através do recurso à estampa, expondo, na figura 1, um exemplar em que se pode vislumbrar uma magistral representação do repertório da arte rococó, realizada pelo ornamentador francês Juste-Aurèle Meissonnier.

De origem setecentista, a estampa da figura 1 integra uma obra de tal modo representativa da época que mereceu ser reeditada pela Biblioteca do Instituto Nacional de História da Arte de Paris, onde tivemos a oportunidade de a compulsar. Inspirado por ares de grande originalidade, o traço de Meissonnier revestiu esse exemplar de ornamento de larga singularidade compositiva: construída com base em uma ritmada conjugação de formas curvilíneas que se volteiam e revolteiam, reproduzindo-se qual eco do modelo côncavo da rocalha, motivo decorativo utilizado com mais frequência pelos artistas nessa época. A sutileza do sombreado de baixo contraste produz uma auréola de sobriedade já esperada pela sociedade francesa do século XVIII. Atenção requer a representação floral que se conforma ao todo retratado, mas que também se lança sob o provável comando de um punho ansioso por esvoaçar as formas para criar ambiente propício ao fantasioso no conjunto. O caráter intencionalmente assimétrico dos elementos presentes na figura (cartelas, molduras) transmite tamanha força ao modelo que a estampa se torna anúncio de um novo estilo marcadamente distinto do antecessor barroco. 


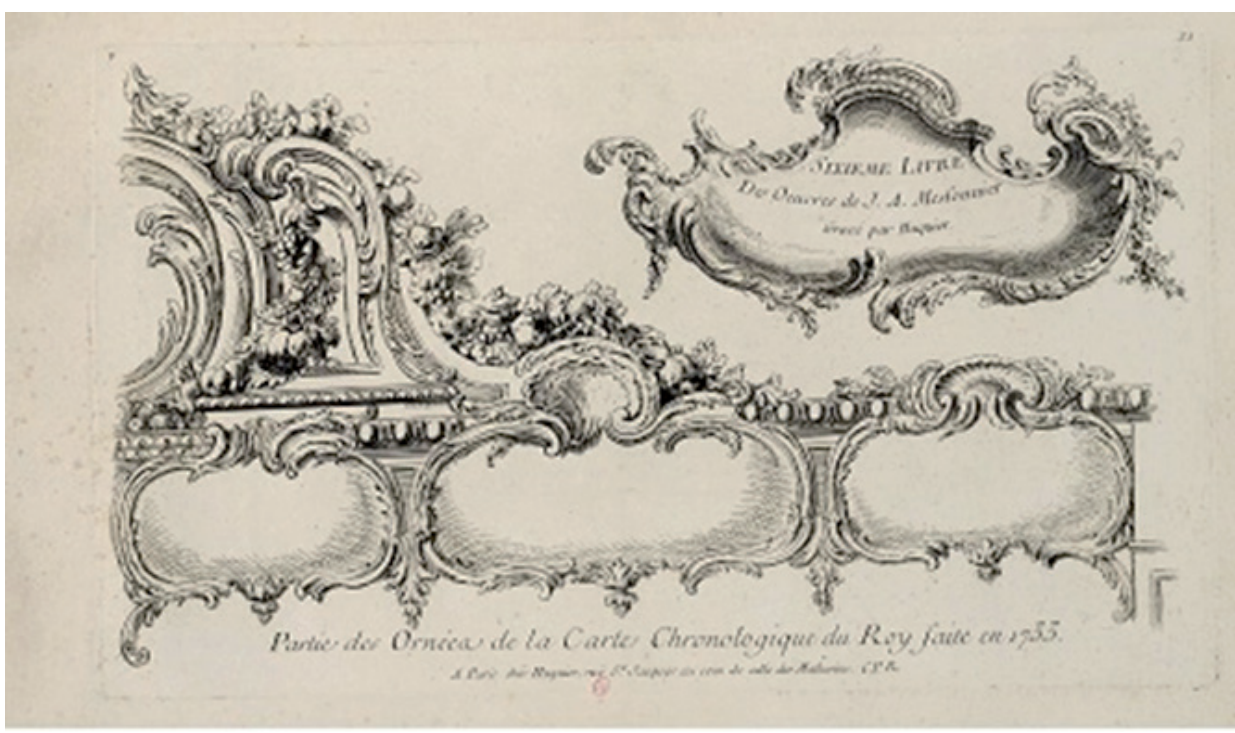

Figura 1. Estampa de ornamento. Juste-Aurèle Meissonnier. 1733.

Face ao elevado grau de apuro técnico e ao proeminente teor estético, as estampas suscitavam nas aspirações decorativas da sociedade setecentista o acolhimento dos então conhecidos fenômenos da repetição e da imitação, o que não destituía o valor artístico das produções ornamentais deles resultantes. Bem ao contrário, pois "é bom lembrar que o curso livre da cópia, na época, pode ser entendido como uma forma de expressar admiração". ${ }^{40}$ Imitar ou copiar não significava uma espécie de desvalorização da criatividade, mas o reconhecimento de méritos das mãos que conformaram novos caminhos na arte. "A execução da imagem [obras de arte em geral] baseava-se em modelos pré-existentes, e copiava, se não fielmente, pelo menos dentro do mesmo padrão e da mesma tipologia". ${ }^{41}$ Desta sorte, "era considerado mais habilitado aquele que copiasse o mais fielmente possível os modelos ou os mestres". ${ }^{42}$

Não se perca de vista que, mesmo em meio às peculiaridades da nova proposta estética, os desenhistas e gravadores do século XVIII mantiveram profunda admiração pelos artistas do classicismo e respeitavam os cânones ou padrões por eles estabelecidos. Por longo tempo, na história e na cultura do vasto mundo ocidental se seguiu como parâmetro de qualidade estética os referenciais implantados pelos clássicos, ainda que, na maioria das vezes, se tenha notado o acréscimo de dados inovadores.

A admiração pelos clássicos fez reafirmar a função pedagógica das estampas. Nos ateliers, elas eram utilizadas com o fito de proporcionar boa formação de artesãos e artistas, de modo especial aqueles que se dedicavam à aprendizagem das expressões da arte requerentes de maior superfície, como são os casos da talha e da escultura. Para o domínio dessas manifestações artísticas se propugnava como necessidade fundamental o desenvolvimento da habilidade de desenhar e para esse concurso as estampas se aplicavam de modo eficaz. Algumas dentre elas foram deliberadamente realizadas para essa causa. Há registros de manuais de arquitetura da época que avivavam a imprescindibilidade do exercício do desenho e, por essa razão, eram acompanhados de estampas. ${ }^{43}$ Episódicos e esparsos, esses manuais se apresentavam como real fonte inspiradora para a criação da estética rocaille.
${ }^{40}$ OLIVEIRA, Myriam Andrade Ribeiro de, op. cit. , p. 497.

${ }^{41}$ FLEXOR, Maria Helena Occhi, op. cit.

${ }^{42}$ Idem.

${ }^{43}$ Ver DECROSSAS, Michael et FLÉJOU, Luice (dirs.). Ornements. XVe-XVIIIe siècles: chefs-d'oeuvre de la Bibliothèque de l'INHA, collection Jacques Doucet. Paris: Mare \& Martin/ Inha, 2014. 
No quadro geral de entendimento da história da ornamentação gráfica, torna-se significativo e necessário considerar que as estampas apresentavam um nível acentuado de aplicabilidade e adaptação aos gostos da moda. Além do que, seus temas podiam ser transpostos para diversos materiais e suportes e isso porque elas emergiram como fonte para uma relativamente expressiva parcela de manifestações da arte.

Embora pouco se considere, a expressão da arte que de modo mais imediato acolheu a influência da decoração rocaille das estampas foi a ornamentação de manuscritos que, sob esse influxo, também revelou o dito 'gosto moderno'. A habilidade em reproduzir, adaptar, criar e recriar daqueles que executavam a arte de ornamentar merece ser posta em destaque. Nessa perícia técnica e na capacidade de apropriação e reconstrução iconográfica tiveram origem desenhos dignos de apreço. No entanto, por não terem sido assinados, quedaram-se no anonimato. Dentre esses desenhos, há espécimes que proscrevem toda dúvida a respeito da influência da gravura na ornamentação dos documentos do Brasil no século XVIII, como atestam as figuras 2 e 3 postas mais adiante.

Para o estudo da ornamentação, expõe-se aqui, na figura 2, uma carta geográfica do Rio Grande do Sul, de origem setecentista. O autor optou por emoldurar todo o mapa e o fez com primor, posto que recorreu ao vocabulário da arquitetura religiosa do Setecentos, dando-lhe um tratamento baseado no chiaroscuro tipicamente barroco, tendente, no entanto, ao rococó, como se pode, com aplicada atenção, verificar. O mapa, assim, reclama a atenção exatamente pela presença dos ornatos, cujo traçado denota claro seguimento das normas de um estilo que já começava a dar sinais de vida no Brasil e que, caminhando, por certo período, pari passu ao barroco, se ia afirmando em virtude da sua fertilidade ornamental.

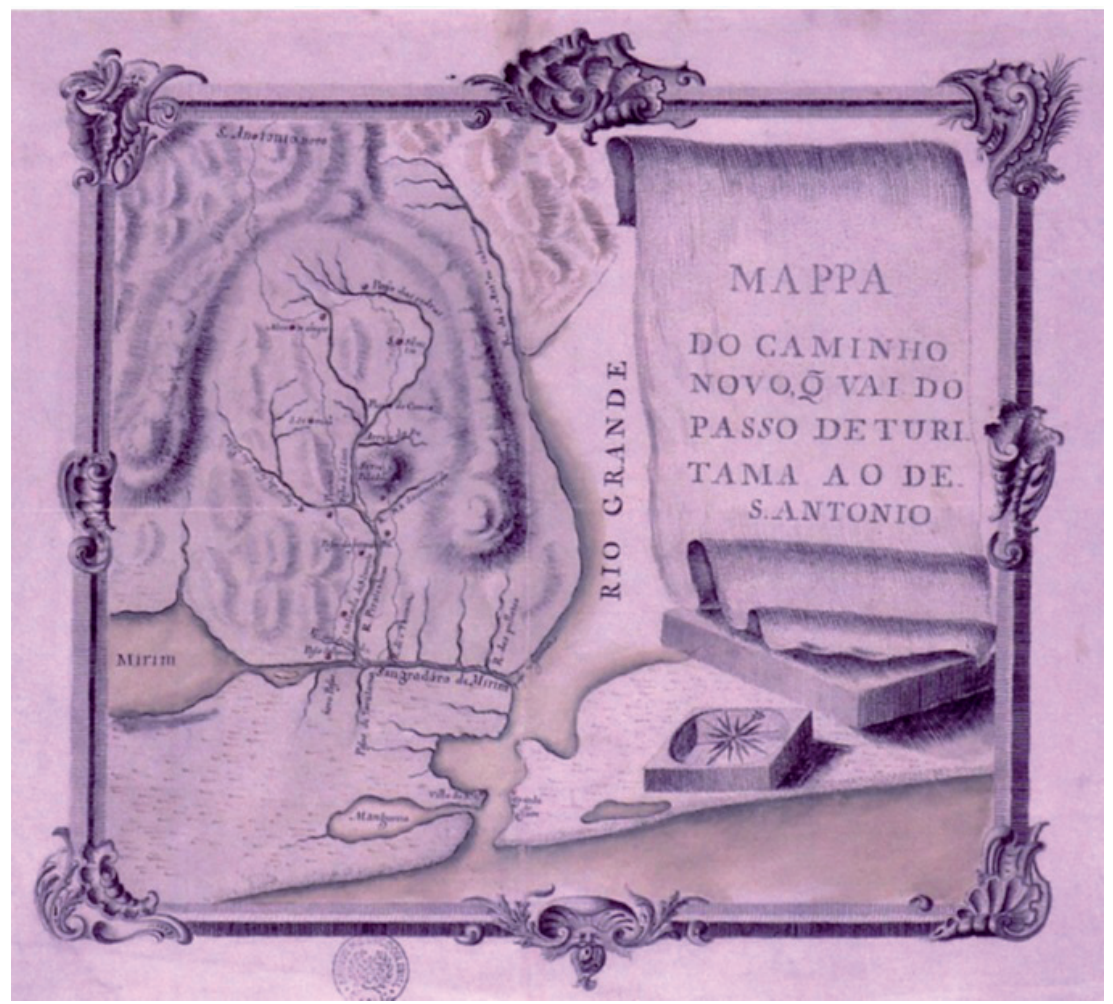

Figura 2. Carta geográfica. Sem autoria. 1753. 
No sombreamento, o autor demonstra grande habilidade, assim como no desenho que revela maestria, visto que assimétrico nos pormenores e equilibrado no conjunto, formando uma composição em que o geometrismo e o classicismo se entrecruzam, através da reprodução de elementos de um imaginário que foge um pouco da linguagem religiosa para desembocar numa expressão mais ornamental, sintomática de avanço na transmutação estilística, ou na travessia para uma nova estética. Observe-se, na figura em alusão, a sintonia com o rococó que se apresentou com esplendor em algumas expressões da arte no Brasil do século XVIII. Esse caráter de exaltação e fulgor decorativo rocaille, apesar de apresentar maior conformação na arquitetura e na escultura, pode também ser atestado na ornamentação de manuscritos, dos quais as cartas geográficas se levantam com propriedade identificativa da índole ornamental. A configuração dos ornatos teve como provável referência para leitura e reprodução a padronagem difundida através de impressos de origem francesa ou alemã, considerando-se o transporte desses dados pela ação colonizadora portuguesa. É de consenso que "Portugal era o motor Atlântico e dominava boa parte dos trópicos no século XVIII". ${ }^{44}$ Essa influência europeia pode ser verificada no exemplar de carta geográfica. Tomando como referência a estampa do mestre Meissonnier (figura 1), logo se encontra a paridade dos elementos vegetalistas e dos concheados.

A frugalidade e a serenidade que abrandaram o forte esquema de organização ornamental barroca conduzem a um entendimento mais ampliado sobre a compleição deste exemplar. Atribuindo relevo à concentração regular de unidades ornamentais ao longo da cercadura, os arranjos não somente a integram como a definem. Contudo, a composição dos elementos ornamentais esparsos, mas coordenados, impregna esse exemplar de um inconfundível feitio rocaille.

Pode muito apropriadamente ser considerado como digno exemplar da arte brasileira o mapa apresentado na figura 3. Trata-se de um mapa comercial da capitania do Rio Negro. ${ }^{45} \mathrm{O}$ apuro técnico e a cor avermelhada do espécime infundiram na composição em aguada, técnica de desenho comum à época, um cunho solene. Revelando domínio da linguagem visual, o autor se mostra conhecedor das formas clássicas, porque constrói uma composição com austeridade e rigor próprios de um classicismo típico da fase final do Renascimento, porém cumulada do discurso visual barroco. No entanto, a composição é perpassada pela soltura e leveza almejadas pelo espírito e modo de expressão rococó. Uma vista pouco apurada sobre a figura 3 deduziria por uma simetria. Um olhar refinado, contudo, reconhecerá, na disposição das formas, uma tênue assimetria que não corrói o equilíbrio, mas, bem ao contrário, para ele contribui e o assegura sem o compromisso de uma combinação equitativa de elementos repetitivos.

Os concheados, as folhas de acanto, as reentrâncias, o contraste atenuado e um suave sombreamento, aliados à assimetria, conduzem ao reconhecimento de uma obra típica do terceiro quartel do século XVIII (no Brasil), quando elementos do rococó começavam a se afirmar com maior nitidez, sem, contudo, desnudar o caráter barroco animador desse desenho. Aos elementos destacados se acresce o tom avermelha do que contribui para a leitura de uma obra com cariz ornamental digno de nota.

Importa também lembrar que o mapa da figura 3 ostenta uma cercadura com decoração similar à de alguns dos seus congêneres contemporâneos, que registram a preocupação setecentista com a função

${ }^{44}$ NÓBREGA, Michael Douglas dos Santos, op. cit., p. 45.

${ }^{45}$ Fundada em 3 de março de 1755, a chamada Capitania de São José do Rio Negro, embora independente, era subordinada ao Estado do Grão-Pará e Maranhão. Cf. SERRÃO, Joel e MARQUES, A. H. de Oliveira. Nova história da expansão portuguesa: o império luso-brasileiro (17501822). Lisboa: Estampa, 1986. 
${ }^{46}$ No original: "parfois même plus d'importance et plus d'agrément que le sujet principal". LIEURE, Jules, op. cit., p. 22 (tradução nossa).

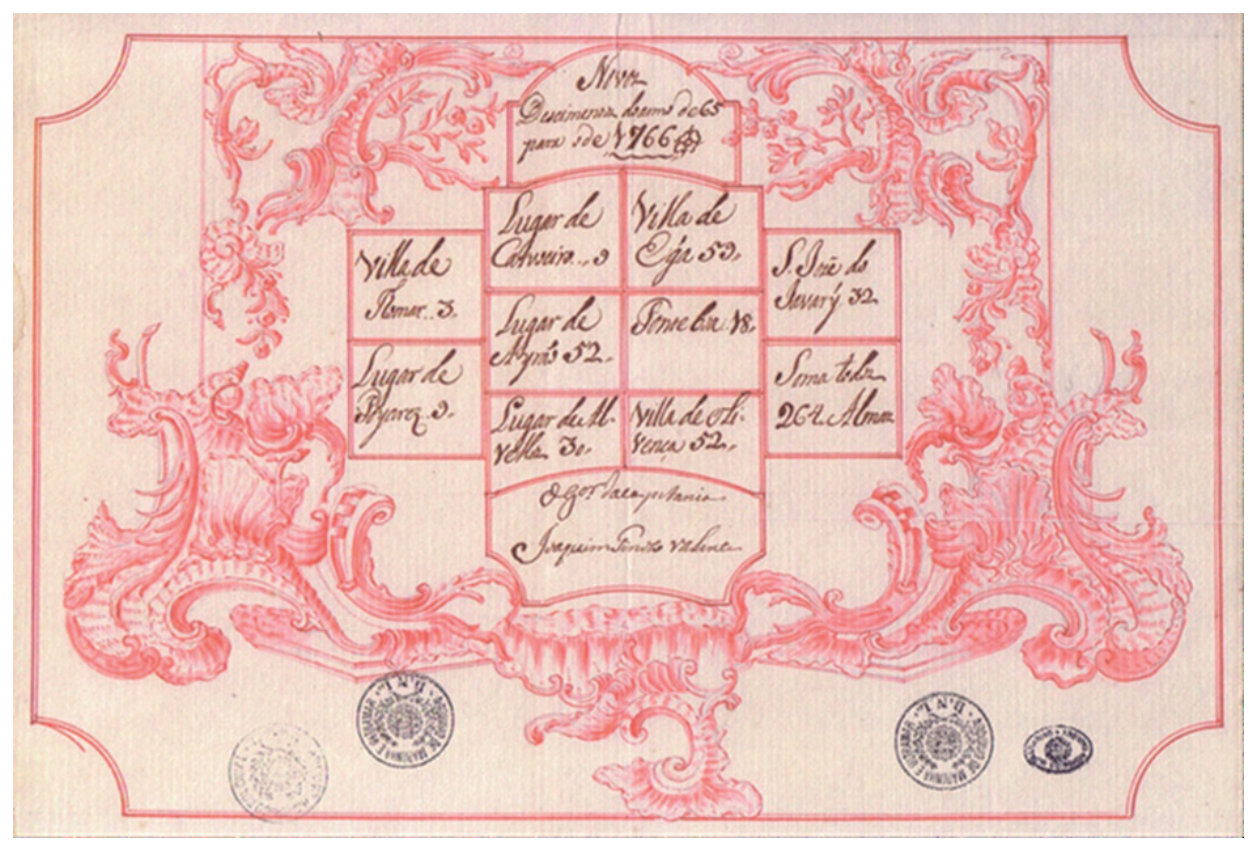

Figura 3. Mapa comercial do Rio Negro. 1766.

ornamental do desenho. Atenção às formas onduladas que se movimentam com uma sensualidade delicada. Elementos florais transmitem graça e leveza ao conjunto, provável influência do envolvimento do autor com a estética rocaille. A representação de folhagens da figura acena, por seu turno, para essa possibilidade.

A aplicação do tom claro do vermelho, amenizando a carga vibrante desta cor, pode traduzir uma visão serena da vida, uma concepção de mundo eivada de brandura, materializada no modo de projetar e organizar o ambiente social, que também perpassou boa parte das sociedades europeias no século XVIII. Reflexo desse sentimento, os ornatos eram recobertos pela sobriedade de tons para o que a técnica do desenho aquarelado se prestava com eficiência e adequação. A ornamentação de per si deve ser entendida como a chave da leitura estética dos desenhos, em razão das formas curvas que exibe, da harmoniosa disposição de côncavos e convexos que, compactuando com a suavidade de tons, introduz no conjunto ares de transparência e luminosidade. Essas características deixam evidente um sucinto abandono da proposta barroca e uma leve marcha em direção a novo projeto acentuadamente ornamental insuflado pelo rococó.

Era recorrente a ornamentação de manuscritos se apresentar sob a forma de cercadura. A esta se atribuiu sempre atenção, visto que ocupavam um espaço de real valor, chegando a ter "às vezes, até mesmo, mais importância e mais atrativo que o assunto principal". ${ }^{46}$ Em geral, eram, em grande parte, comandadas por força do exercício da caligrafia e, no caso do rococó, prestando-se a um intento meramente ornamental, sem obediência a ditames quaisquer da simbologia cristã, como se pode exemplificar na figura 3 destituída de revestimentos ideológicos ou espirituais, deixando à parte dados que para esses sentidos também convergiriam, como a representação de flores.

Essas particularidades envolvem o manuscrito da figura 3 em uma marcante dificuldade de classificação estética. De um lado, a estrutura clássica e as formas acentuadamente barrocas; de outro, o refinamento e a 
delicadeza dos moderados, mas evidentes, motivos rocaille. Entende-se essa dificuldade pelo fato que "na segunda metade do século XVIII, as doutrinas estéticas do barroco são substituídas pelas do rococó. O luxo permanece, mas se evidencia de um modo mais discreto, alastrando-se a uma base social mais ampla, diversificando-se na escala social dos encomendantes" ${ }^{\prime 4}$ Não se perca de vista que na época (segundo a datação) do mapa em questão (terceiro quartel do século XVIII), Portugal havia retomado o classicismo; o Brasil, porém, permanecia na expressão barroca que se mesclava com os rebentos da ornamentação rocaille, e de tal descompasso decorrem a sutileza e a complexidade na análise.

Se o olhar percorrer a estampa exibida na figura $1 \mathrm{e}$, logo em seguida, o mapa da figura 3 encontrará paridade nas formas e sobreposição, ou melhor, cruzamento de peculiaridades no desenho. Não passarão despercebidas as curvas em " $\mathrm{C}$ ", a dinamicidade das formas conchoidais e florais (estas ainda que parcas), a elaborada aplicação do atenuado, mas firme, sombreado na cercadura do mapa. Esses atributos modelam na ornamentação do mapa um semblante rococó. O barroco punha a tônica nos símbolos religiosos, como imagens de santos e anjos, fazendo eco ao discurso catequético e doutrinal da Igreja Católica; punha também acento no exagero e na abundância sempre chocantes. No rococó era evidente a noble simplicité articulada com um claro requinte. No entanto, há que se esclarecer que nos ornatos selecionados e aqui expostos, o tímido caráter não oculta a intensidade do espírito, nem a lentidão dos passos do estilo encobre a lucidez do percurso, nem a clarividência de objetivos e metas. Se é verdade que na gênese desses ornatos se encontra um provável impulso barroco, seu nascimento e sua evolução derivam de planejada maturação rocaille.

Interessa aqui reconhecer que não se registra perfeita correspondência estética entre a produção artística colonial (brasileira) e a metropolitana (portuguesa), o que leva a considerar os ornatos apresentados nas figuras 2 e 3 como expressões de culturas distintas que, no entanto, sorveram de comum fonte de inspiração, como atestam as estampas europeias. Assim, os signos da ornamentação, tais como concheados, curvas, flores, folhagens, dentre outros, por pertencerem ao universo figurativo corrente às estampas e às outras artes visuais (de modo especial a escultura, a arquitetura e a mobiliária) constatam a possibilidade de adaptação iconográfica, fundamentando o que se pode considerar como uma miscigenação estética. Ademais, a ausência de absoluta correspondência tem plausível explicação também no fenômeno já referido da cópia. “Imitar, aqui, não significa simplesmente copiar servilmente, mas selecionar o que imitar e reelaborar seu modelo mediante conhecimentos de regras da arte, da natureza e das criações antigas, concepção pertinente ao período. Ao mirar modelos gravados como fontes criativas, os artistas atualizavam-nas, em suas obras, a partir de concepções estéticas e habilidades que os circundavam" ${ }^{48}$

A cópia, de certa maneira, pode explicar essa hibridação e de modo algum resultava de uma reprodução irrefletida. O contato com elementos das culturas envolvidas e o cruzamento de dados identitários desdobravam-se em possibilidades de multivariada interpretação e de reconstrução, refletidas nas obras de arte como significativos acréscimos. Foi essa habilidade de reelaboração, de recriação, que fez despoletar a transição do barroco para o rococó. Myriam Ribeiro de Oliveira chega mesmo a afirmar que a fase do rococó no Brasil "foi o período mais criativo da contribuição mineira para

${ }^{47}$ MARQUES, Maria da Luz Vasconcelos e Souza Paula. Mobiliário português do aparato do século XVIII: credência, consolas e tremós. Dissertação (Mestrado em História da Arte) - Universidade do Porto, Porto, 1997, p. 8.

${ }^{48}$ SANTIAGO, Camila Fernanda Guimarães. Os usos de gravuras europeias como modelos pelos pintores coloniais: três pinturas mineiras baseadas em uma gravura portuguesa que representa a Anunciação. Temporalidades, v. 3, n. 1, Belo Horizonte, jan.-jul. 2011, p. 189. 
${ }^{49}$ OLIVEIRA, Myriam Andrade Ribeiro de., op. cit., p. 497.

${ }^{50}$ MINGUET, Philipe. Esthétique du rococo. Paris: J. Vrin, 1966, p. 676. No original: "il faut penser les styles de façon relative. Le classicisme détient une priorité de droit. Le baroques'en écarté, il ne vise plus à la beauté, mais au sublime dans as puissance et sa grandeur. Le rococó de son côté vise au jeu de la grâce" (tradução nossa).

${ }^{51}$ Ver PEDRONI, Fabiana, op. cit., p. 80. a arte colonial" ${ }^{49} \mathrm{E}$ pode-se aqui comprovar, através dos exemplares de ornamentação em estudo (figuras 2 e 3), e afirmar que essa criatividade,em especial no âmbito da decoração de manuscritos, não estava circunscrita às Minas Gerais.

A análise dos desenhos aqui realizada permite constatar um hibridismo de estilos, aliás recorrente em vários exemplares da arte luso-brasileira do século XVIII, quando o barroco e o rococó viviam de mãos dadas, com predominância ora de um, ora de outro, sendo que, no caso da ornamentação gráfica, tomando como referência os espécimes em foco (figuras $2 \mathrm{e}$ 3) este último estilo deixou sinais mais elucidativos. Contudo, "é preciso pensar os estilos de modo relativo. O classicismo detém uma prioridade de direito. $\mathrm{O}$ barroco se distancia, pois não visa mais à beleza, e sim ao sublime em sua potência e grandeza. O rococó, por seu turno, visa ao jogo da graça". ${ }^{50}$ Portanto, os estilos paralelos ou sucessivos se interceptam através da partilha de elementos comuns, dialogam apoiados na comunhão de signos e, por vezes, anulam as contradições de seus propósitos, quando se acolhem mutuamente.

Seria uma temeridade ajuizar pela exclusiva atuação da gravura como influente no desenvolvimento do rococó no Brasil. No entanto, do papel que ela exerceu na evolução da ornamentação rocaille dos manuscritos não há que duvidar. Provam-no as equivalências formais, estilísticas e iconográficas. Grande parte do vocabulário ornamental constitutivo da arte brasileira do século XVIII era difundido pelas estampas europeias que, desse modo, operaram como uma gramática para a linguagem do estilo rococó.

O reconhecimento de que as gravuras não foram a única fonte, mas certamente a principal referência, não representa uma restrição da criatividade, mas implica afirmar um influxo enriquecedor da concepção e produção de obras de arte, elaboradas e realizadas mediante a confluência de elementos culturais relacionados às vivências do ornamentador, seu entendimento da arte, sua formação. É a partir da aproximação entre a fonte inspiradora e o contexto de sua própria história, suas experiências e saberes, que o autor dos ornatos exerce a faculdade de criar. O desenvolvimento da comunicação visual se fundamenta não somente na reprodução do que se vê, mas também e com maior propriedade na transcrição do que se sabe, na experiência de conhecimentos adquiridos na vivência em sociedade, resulta, deste modo, da equipagem cultural.

A especificidade da difusão do rococó e os caminhos trilhados pelo estilo podem esclarecer a própria natureza da arte de ornamentar: apropriação do conjunto de símbolos peculiares das culturas e sociedades implicadas, interpretação dos dados, elaboração temática com reprodução e/ ou recriação de signos. Em abono da verdade, esse é um caminho encetado por toda expressão da arte. É desta maneira que o ornato ultrapassa sua existência enquanto paramento identificador de estilo e se reveste do caráter estético distintivo de toda manifestação artística. Nesse sentido, toda arte é, na sua essência, ornamental - e aqui se evoca o sentido etimológico do termo. Na sequência dessa linha de pensamento, vale mencionar que pesquisadores atentos à história do ornamento têm chegado à compreensão de quefazer história da arte abstendo-se de fazer a história da ornamentação seria assumir o risco de incorrer em problemas delicados ${ }^{51}$, sobretudo em se tratando da arte do Brasil colonial.

Não se deve perder de vista que tratamos aqui de uma expressão da arte (o ornato) que, embora se tenha consolidado no Oitocentos (no Brasil), 
já havia dado mostras de vida no século XVIII na Europa e no Brasil e, por essa razão, não deve haver estranhamento face à ocorrência das consequentes interpenetrações das balizas temporais, que em nada desautorizam a análise realizada, mas põe em destaque o caráter inusitado do modo de criação, desenvolvimento e difusão do estilo rococó.

A necessidade de se entender melhor o papel que o rococó desempenhou na História da Arte Brasileira fez o olhar incidir, mais uma vez, sobre a arte decorativa. E, nesse sentido, toldar a atenção sobre a ornamentação de manuscritos vem exaltar não somente fatores de ordem técnica específicos da representação gráfica, mas, sobretudo, significa reconhecer o valor do desenho enquanto formador e expressão do pensamento, fator que desempenha a mais segura função na apreensão e no evoluir da ciência, reflexo ímpar da história do pensamento e das culturas.

O desenho é um dos mais convincentes meios de que o ser humano se utiliza para desenvolver sua habilidade de criar novas formas e estetizar a natureza. O caminho da ornamentação é incontornável ao historiador da arte, porque lhe possibilita conhecimento mais enraizado na origem do ato de criação que parte stricto sensu de um projeto, aqui entendido como desenho. Universalmente constitutivo da essência das artes, o ornato é um testemunho da faculdade humana de representação. Manifesto, por vezes, em ínfimas dimensões, cada ornato é um horizonte de infinitas possibilidades em que se pode encontrar a amplitude do ato de criar. Orococó abriu as portas para que a graça e o requinte se tornassem fantasia na realidade de um novo modo de conceber a vida, razão por que toda a decoração desse estilo não pode ser vista como apêndice da arte do século XVIII, ou como um desmembramento do barroco. O rococó deu luz à fantasia, estigmatizando a História da Arte de um labiríntico contorno da existência através da, paradoxalmente moderada, aspiração ao absurdo. Uma simbiose de sonhos e naturalismo, um cruzamento de natureza e ficção, uma conciliação de luxo e simplicidade, um entrelaçamento de rompante e inação.

À luz da reflexão realizada neste texto, que pôs em destaque os percursos e as expressões peculiares do estilo rocaille, podemos afirmar que uma condensada harmonia entre o real e o sonho proporcionou uma estética fundada no baixo contraste, na quase nula contradição, conspirando para a gestação das formas de puro requinte que insuflaram o frescor de uma nova aurora na ornamentação de manuscritos: o despertar de outro e singular estilo da arte no Brasil do século XVIII. Voilà le rococo!

Artigo recebido em 25 junho de 2019. Aprovado em 8 de setembro de 2019. 